\title{
Lafayette Rodrigues Pereira*.
}

\author{
Ernesto Leme \\ Catedrático de Direito Comercial na Faculdade \\ de Direito da Universidade de São Paulo.
}

Meus Senhores.

Das várias facetas sob as quais se pode estudar a personalidade de Lafayette Rodrigues Pereira nenhuma sobreleva, sem dúvida, a sua condição de mestre de direito. O seu permanente magistério deriva de seus livros, não de uma cátedra universitária, que jamais ocupou. Antes, quando convidado certa vez para assumir a cadeira de direito civil na Faculdade do Rio de Janeiro excusou-se, alegando falta de tempo. E a Francisco Cesário Alvim, então estudante, que relata o episódio, argumentava: "Cujácio, e era Cujácio, estudava quatorze horas de um dia para dar uma lição no dia seguinte" . (Apud Rodrigo Octavio, Minhas Memórias dos Outros, Última Série, p. 81).

Mas, ao lado do jurisconsulto exímio e do tratadista insuperável, juntavam-se nessa complexa figura os atributos mais diversos, que lhe valeram os mais consagradores triunfos em outras atividades: parlamentar, estadista, diplomata, homem de letras, deixou um estendal de luzes em sua trajetória, mercê dos esplendores de sua inteligência, de sua cultura, de sua dignidade exemplar.

Nascido na província de Minas Gerais, município de Queluz, que hoje tem o seu nome, aos 28 de março de 1834 , era seu pai o coronel Antônio Rodrigues Pereira, depois

* Conferência proferida no Instituto Histórico e Geográfico de São Paulo, a 30 de novembro de 1960 . 
Barão de Pouso Alegre, de quem Francisco de Paula Ferreira de Rezende nos informa que "era um velhinho magro e têso, e tinha sempre a cabeça tão erguida, que incomodava extremamente a quem com êle falava. Era, entretanto, tão forte que, apesar da sua idade, saía da sua fazenda dos Macacos, que fica ao pé da estação de Buarque de Macedo, e chegava no mesmo dia a Ouro Preto", (Minhas Recordações, p. 341).

Havendo estudado preparatórios no Colégio de Congonhas do Campo e aprimorado seus estudos de latim com o tio, padre Felisberto Rodrigues, encaminhou-se para São Paulo, onde viria cursar as aulas da Academia de Direito ${ }^{1}$ "Nasceu jurista", vaticinava o pai, mas, nunca poderia supor que aquêle jovem de dezenove anos, que se acolhia à sombra

1. Encontra-se no Arquivo da Faculdade de Direito, na pasta n. ${ }^{\circ}$ 1908, de 1853, referente a Lafayette Rodrigues Pereira, a seguinte certidão:

"Domiciano Teixeira Campos, Presbitero Secular do Habito de S. Pedro, e Vigario Encomendado da Freguezia da Villa de Queluz.

"CERTifico que no L. 10 de Baptisados desta Freguezia a flls. 20 vs. consta o ascento do theor seguinte. - Aos tres de Outubro de mil oito centos e trinta e quatro, na Capella de Santo Amaro o Padre Manoel Vieira da Cruz baptisou e pos os Santos Oleos a Lafayette parvolo filho legitimo do Capm. Antonio Rodrigues Pereira, e Dona Clara Ferreira de Azevedo sendo Padrinhos o Reverendo Vigario Francisco Pereira de Assis, e Dona Luiza Rodrigues de Jesus. O Vigro. Candido Taddeu Pereira Brandão. Nada mais continha o referido escrito q. fielmente copiei. Por ser verdade o affirmo in fide Parochi. Villa de Queluz 7 de Janeiro de 1852. O Vigro. Domiciano Teixeira Campos".

Os documentos contidos nesse dossier estão chamuscados pelo fogo, em virtude do incêndio de 1880. E entre êles se encontra certidão de haver Lafayette Rodrigues Pereira sido aprovado plenamente nos preparatórios de Latim, Francês, Inglês, Retórica, História e Filosofia e simplesmente em Geometria. Requereu matrícula no $10^{\circ}$ ano, sob n. ${ }^{\circ} 45$, a 7 de março de 1853; no $2 .^{\circ}$ ano, a 10 de março de 1854; no $3 .^{\circ}$ ano, não consta; no $4 .^{\circ}$ ano, não consta, (tendo sido aprovado plenamente nas matérias do $3 .^{\circ}$ ano) ; requereu matrícula no $5 .^{\circ}$ ano, a 2 de março de 1857. Colou grau de bacharel a 20 de novembro de 1857, sendo presidente do ato o doutor Joaquim Ignacio Ramalho. 
das arcadas do Curso Jurídico viesse a se converter um dia no mais autorizado mestre de direito civil em nossa terra.

O juízo não é sòmente meu; é também de Pedro Lessa. Recebendo a Alfredo Pujol na Academia Brasileira, na cadejra ocupada por Lafayette, em sucessão a Machado de Assis, proclamava o eminente magistrado e jurisconsulto a primazia daquele sôbre o próprio Teixeira de Freitas. "Contemplai-o por um momento de crítica, feita em meia dúzia de períodos irretorquiveis, como axiomas matemáticos, à classificação dos direitos, longa e penosamente engendrada por Teixeira de Freitas. $O$ exato conhecimento da função lógica das classificações, tanto nas ciências sociais, como nas inferiores, facultou-lhe o reduzir o famoso trabalho, tão preconizado, do grande consolidador das nossas leis civis, à mais perfeita e evidente inutilidade". .

Não teve Lafayette o "ensejo de revelar o seu espírito criador; pois, não se lhe outorgou a incumbência, que mereceu mais do que ninguém, de elaborar o nosso Código Civil". Por isso, acentua Pedro Lessa, "a sua missão foi a de elucidar, metodizar e expor sistemàticamente os dogmas do nosso direito. Aí se revelou com o mais intenso brilho a sua argúcia no interpretar as leis, o seu método no explaná-las sistemàticamente, a sua clareza inigualável em ambas essas operações lógicas, a concisão e a elegância do seu estilo exemplar".

O seu devotamento aos estudos do direito já se fazia notar desde os bancos acadêmicos. Guarda o arquivo da Faculdade cópia do ofício dirigido ao Ministro do Império pelo diretor, Manuel Joaquim do Amaral Gurgel, a 7 de dezembro de 1855 e no qual destacava, como os melhores alunos do terceiro ano, Lafayette Rodrigues Pereira e João Batista Pereira, que presidiu a provincia de São Paulo em 1878 e foi o autor do Código Penal de 1890. A Revista da Faculdade de Direito, (vol. xxxiv, fascículo $2 .^{\circ}$, p. 25/39), publica a dissertação apresentada por Lafayette, então estudante do quinto ano, sôbre Prática e Teoria do Processo, abordando êstes temas: Quais os juizes, que pelo direito 
moderno, têm jurisdição prorrogável? O juiz de órfãos tem jurisdição prorrogável?

A leitura dêsse trabalho, datado de 28 de julho de 1857, dá-nos a marca, já a êsse tempo, do espírito lógico de Lafayette, do seu zèlo pela linguagem, do seu cuidado na indicação das fontes. Nele se evidencia o futuro mestre dos Direitos de Familia, publicados em 1869, a que se deveria seguir, em 1877, o Direito das Cousas, obras insuperáveis e insuperadas, a que os juristas diàriamente recorrem, para beber lição de doutrina e de vernaculidade. E um dia, quando Martinho Campos perguntava, ao Ministro da Justiça, como subira tão depressa aos Conselhos da Coroa, Lafayette poderia responder, orgulhosamente: "Subi montado em dois livrinhos de direito"...

Ao orgulho de Lafayette há de se fazer referência como atributo da própria herança paterna, a cuja vaidade Ferreira de Rezende alude com certa acrimônia em seu livro de memórias. $\mathrm{E}$ assim depõe a propósito do pai a escritora Albertina Berta: "Êle muito confiava em si, não buscava a opinião de outrem para ratificar o seu julgamento. Considerava-se o seu censor mais severo, o mais inexorável, sempre atento a corrigir, a emendar, numa caligrafia miúda, os manuscritos que ainda se encontravam em seu poder". (Apud Rodrigo Octavio, op. cit., p. 89).

Ao dar a lume, aos 35 anos de idade, os Direitos de Família, tinha Lafayette o espírito amadurecido no trato da jurisprudência. A sua independência científica se revela desde as primeiras linhas da Introdução. Adota a classificação do direito civil de que foram iniciadores Heise e Thibaut, não porque lhe parecesse a mais perfeita, "senão como das inventadas a melhor e a mais acomodada para uma distribuição regular das diversas instituições". Critica a orientação de Leibnitz, fundando sua classificação nas causas geradoras dos direitos: natureza, convenção, posse, sucessão, delito. Porque, "além de assentar em uma enumeração inexata, é falso o sistema porque a diferença de causas não determina a diferença de direitos". Aborda, 
logo após, a classificação preconizada por Teixeira de Freitas, "o sábio e eminente jurisconsulto, que como a mestre estamos habituados a respeitar, todos que nos damos a esta ordem de estudos", combatendo a sua classificação baseada na diferença entre direitos pessoais e reais.

Acentua após, no campo do Direito Civil Pátrio, o alto papel desempenhado pela doutrina na elaboração científica. "Tendo por órgãos professôres e escritores, ela gira em uma esfera mais elevada do que a jurisprudência prática; obedece à inspiração de uma ordem superior; caminha iluminada pelas luzes da filosofia; - os tribunais esforçamse por chamar o Direito às necessidades da vida; a ciência lida por aproximá-la do seu ideal".

No Prefácio do Direito das Cousas, assim delimita Lafayette o campo que vai lavrar: "Tomado nos seus lineamentos fundamentais, o Direito das Cousas se resume nisto: em definir o poder do homem, no aspecto jurídico, sôbre a natureza física, nas suas variadas manifestações; e em regular a aquisição (por título singular), o exercício, a conservação, a reivindicação e a perda daquele poder, à luz dos princípios consagrados nas leis positivas". E conclui: "De escritores nacionais e estrangeiros extraimos com a maior liberdade tudo que fazia ao nosso intento. Nesta praxe não fizemos senão imitar os exemplos dos nossos predecessores. Um dêles disse francamente: "Je prends mon bien où je le trouve". E outro justificava aquela usança com êste pensamento de Fontenelle: "Ce n'est qu'en montant sur les épaules des autres que nous pouvons voir d'un peu loin".

Mell primeiro contacto com êsse livro foi em 1917, quando cursava o terceiro ano de direito. Constituíu, desde então, meu livro de cabeceira, para o estudo dos problemas dessa parte do direito civil. Porque nada conheço em nossa literatura juridica que se lhe equipare. Daí o louvável empenho do embaixador José Bonifácio de Andrada e Silva de o reeditar, em 1922, adaptando-o ao Código Civil, como já o havia feito em 1918, quanto aos Direitos de Família. 
Publicou ainda Lafayette, em 1902, os dois volumes dos Princípios de Direito Internacional. Depois disso, dêle apenas tivemos, em matéria jurídica, o Projeto do Código de Direito Internacional Privado, editado pela Imprensa Nacional, em 1911, e os dois volumes de Pareceres, publicados após a sua morte pela Livraria Editora Cândido de Oliveira, em 1921.

Revela Rodrigo Octavio, (op. cit., p. 88), um aspecto ignorado da atividade intelectual de Lafayette: o seu culto à poesia. Chegou mesmo a confiar a seu dileto amigo Max Fleuiss uma composição em versos heróicos, tradução de Catulo, ou de Lucrécio, autorizando sua publicação. Mas, quando recebeu as provas, para rever, não as devolveu, reclamando, ainda, a devolução do original. .

Ficamos a imaginar, por essa amostra, o que Lafayette não teria realizado no domínio da arte. Com sua imensa cultura clássica e o trato freqüente dos poetas gregos e latinos, devem existir em seu arquivo, guardadas zelosamente pela família, ótimas demonstrações de seu engenho poético. Já o velho Antônio Ferreira proclamava que "não fazem mal as Musas aos doutores". Ao renome do sábio Lafayette há de um dia acrescentar-se êsse florão, como, com as luminosas páginas de Vindiciæ, se evidenciou a capacidade de um crítico literário até então desconhecido.

Havia Sílvio Romero escrito um alentado volume sôbre Machado de Assis. A pretexto de estudar a sua obra poética, exaltava a produção de Tobias Barreto, em cotejo desfavorável para o mestre das Memórias Póstumas de Brás Cubas. Foi quando surgiu na liça um gladiador anônimo, fazendo um inventário demorado das opiniões de Sílvio, cujos erros de apreciação punha em destaque.

A espada do combatente possuía acerado gume. Penetrou duramente na carne do adversário, cuja irritação está patente nas palavras da Nota ao prefácio da $2 .^{a}$ edição dos Estudos Jurídicos de Tobias: "Bem se vê que não conto nesse número o miserável e torpe covarde que escreveu contra mim umas infames e imundas sandices ùltimamente 
no Jornal do Comércio com o pseudônimo de Labieno e que disse que Tobias não passava de um exquisitão de algum talento". . Ao que o autor dêsses artigos, que não era outro senão Lafayette, respondeu com estas palavras contundentes, insertas em nota nas primeiras páginas de Vindiciæ, publicação de Jacinto Ribeiro dos Santos, em 1899: "Quem a uma discussão séria, em linguagem decente, com uma ou outra vivacidade que nem de leve roçou pelo caráter e dignidade pessoal, responde com o insulto soez e banal, à competência com o almocreve e com o arrieiro, certo que se confessa de plano, batido, vencido. Esbraveje, ranja os dentes o Sr. Romero; Labieno não perderá a calma e se manterá no seu modesto papel. Sempre que pelas imediações lhe passarem umas certas figuras, murmurará brandamente como as canas da fábula: Midas, asini habet auriculas"...

A segunda parte do volume é consagrada a uma impiedosa crítica dos Ensaios de Filosofia do Direito, publicados por Sílvio Romero em 1895. Na primeira parte, que no momento nos interessa, faz Lafayette a defesa de Machado de Assis. "O Sr. Machado de Assis", escreve, "é poeta, tem fora de tôda a dúvida a alma de poeta. Sabe sentir, tem fantasia, ideais delicados, sonhos de amor de admirável pureza, crêa pequenos nadas e veste-os de formas impecáveis, burila admiràvelmente fragmentos de bronze, pinta quadros, combina hàbilmente luz e sombras, traça silhouettes caprichosas e exala em formosas endeixas a dor, a saudade. E tudo isto em uma língua correta, limpa, pura, expressiva e em versos de medidas variadas, bem feitos e sempre adaptados ao assunto".

Com apuro de forma e gôsto literário de um apaixonado do belo, assim se exprime Lafayette a respeito do preconceito das escolas: "Esta questão de classificar em escola clássica, escola romântica, escola realista, é um tema sediço, um lugar comum com que se entretêm os espíritos estéreis, amigos de fórmulas vãs, e incapazes de análises penetrantes e profundas dos fatos literários. As obras de 
imaginação, a poesia, o drama, o romance, reproduzem idealizado o que enche a alma humana e faz a trama da vida e da sociedade em cada ciclo do tempo. Todo êste mundo de afetos, de paixões, de idéias, de interêsses muda, transforma-se de períodos em períodos, uns mais longos, outros mais curtos. Não é só o fundo, a substância que muda; mudam também a expressão, as formas, o teor. Cada um dêsses períodos tem, pois, a sua literatura"...

Sôbre a poesia popular: "Certamente a poesia popular é um dos mais belos e fecundos produtos do espírito humano. Ela é por assim dizer a manifestação larga, espontânea, e, portanto, imparcial, da índole e gênio de um povo, das suas tendências, dos seus ideais, das suas crenças, da sua estética e da sua filosofia, mas é um gênero e não tôda a poesia. Nem ela vence, nem suprime, nem diminui a poesia individual, a poesia culta e profunda, a que reproduz em formas aperfeiçoadas e em metros polidos as grandes idéias, os grandes quadros, as alegrias e as tristezas, as lutas, os conflitos, os mistérios da vida humana".

E não precisamos prosseguir. Esse volume, de 253 páginas, seria suficiente para fazer a glória de um escritor. Constitui, no dizer de Alfredo Pujol, "uma essência concentrada de finíssima ironia e de sarcasmo corrosivo, de envolta com uma secreta e maravilhosa intuição da crítica, em períodos vivazes, nervosos, cortantes, vertidos numa locução aprimorada e castiça".

Presidente do Ensaio Filosófico Paulistano, em seu quarto ano de direito, colaborou assiduamente na Revista Mensal dessa associação acadêmica. Em sua colação de grau, aos 20 de novembro de 1857, havendo o presidente do ato, doutor Joaquim Ignacio Ramalho, negado a palavra ao orador da turma, José Ignacio Gomes Guimarães, é o primeiro signatário de um protesto, publicado no Correio Paulistano do dia 25, mercê do qual é envolvido num processo disciplinar, que não teve seguimento.

Nomeado promotor público de Ouro Preto, logo após a formatura, transferiu-se definitivamente para o Rio de 
Janeiro em 1858, iniciando-se na advocacia ao lado de Teixeira de Freitas e, posteriormente, em companhia de Andrade Figueira.

Volta, então, às lides jornalísticas, fundando com Pedro Luís e Flávio Farnese, a Atualidade, órgão político e literário, em que colaborou Bernardo Guimarães. Encontrâmolo, mais tarde, em Le Brésil, no Diário do Povo e em A República.

Rompe-se, com o $14 .^{\circ}$ Gabinete, presidido pelo Visconde de Abaeté, a conciliação entre liberais e conservadores. Falando na Câmara dos Deputados, a 24 de maio de 1859, assim se expressa o presidente do Conselho: "Não sendo, pois, a conciliação um sistema de política, eu entendo que o Gabinete não deveria considerá-la como tal; e é por êste motivo que o discurso da Coroa não empregou esta palavra, e a substituíu por estas - justiça e moderação". Mas, logo a 10 de agôsto caía o Gabinete, assumindo a chefia do govêrno e o Ministério da Fazenda Ângelo Muniz da Silva Ferraz, Barão de Uruguaiana.

Recebe Lafayette, em 1864, do Conselheiro Zacarias, a incumbência de presidir a Província do Ceará. No ano seguinte, passa a presidir a Província do Maranhão, cuja administração deixa a 10 de julho de 1866 . Retornando à Côrte, consagra-se às atividades do fôro e ao culto das letras jurídicas, publicando os Direitos de Família em 1869.

Militando, embora, nas fileiras do Partido Liberal, subscreve Lafayette o Manifesto Republicano de 3 de dezembro de 1870. Por isso, causa verdadeiro impacto emocional nas hostes republicanas, quando se divulga a composição do Gabinete de 5 de janeiro de $\mathbf{1 8 7 8}$, presidido por Sinimbú, a presença de Lafayette na pasta da Justiça. No mesmo ano é eleito deputado pela província de Minas Gerais.

Campos Salles alude ao episódio em seu livro Da Propaganda à Presidência, p. 16: "A entrada do Sr. Lafayette Rodrigues Pereira para a pasta da Justiça tinha por fim, segundo o pensamento atribuído ao Sr. Sinimbú, organizador do Gabinete, "desfalcar os republicanos de tão valioso 
elemento". E não se havia de todo enganado o nobre presidente do Conselho. O surpreendente acontecimento impressionou de alguma sorte o espírito público, chegando-se a sentir, sobretudo em determinadas regiões do país, um movimento de adesão, que levou o alarma ao campo dos propagandistas. Em São Paulo, os chefes republicanos julgaram necessário intervir sem perda de tempo para dar aos correligionários a palavra de ordem e definir a verdadeira orientação ante as complicações que a nova fase da política imperial pudesse acarretar". Nesse sentido se manifestava a 11 de janeiro, pelas colunas de $A$ Província de São Paulo, Francisco Rangel Pestana e, pela Gazeta de Campinas, Manuel Ferraz de Campos Salles. O Congresso Republicano, reunido no mês de março, assim se dirigia "Aos republicanos da Província de São Paulo": "Pensamos que os distintos cavalheiros que figuram à frente da nova situação, e que os seus precedentes mesmo, não podem ter, para nós democratas, o alto valor dos princípios, que constituem o nosso corpo de doutrina, a bandeira sob cujas dobras procuramos arregimentar os brasileiros para a conquista do govêrno do povo pelo povo e realização da República Federativa do Brasil. A situação que ainda agora se abre às esperanças liberais traz o vício originário de tôdas as outras: é pura criação da vontade imperial" .

Eram injustos neste ponto os republicanos de São Paulo. A escolha de um chefe liberal para realizar a experiência democrática da eleição direta era emanação do espírito de justiça que animava D. Pedro II. "Os conservadores aceitavam a eleição direta; contanto que a fizessem. Dependia do imperador mantê-los no poder, com êste compromisso, ou chamar os liberais, que o exigiam, como donos da idéia", (Pedro Calmon, História do Brasil, edição da Livraria José Olympio, V, 1786). E o alto critério do monarca se revela neste tópico de sua carta a Caxias: "Portanto, ambos os partidos a desejam, e eu não tenho senão que achá-la oportuna, entendendo que deve ser o partido liberal, que 
primeiro e constantemente tem pugnado por ela, que a faça".

Isso mesmo Sinimbú anunciou à Câmara, no programa de seu Gabinete: "Sua Majestade, tendo reconhecido a oportunidade de se fazer a reforma eleitoral direta, informado da opinião do país, que não vê hoje nisto uma questão de partido, mas de interêsse geral, e depois de ouvidos os presidentes do Senado e da Câmara dos Deputados, entendeu, e no meu parecer mui lògicamente, que devia caber a realização desta reforma ao partido que primeiro a reclamou, e sempre sustentou como ponto principal de seu programa".

Lafayette não tinha o tabú das formas de govêrno. Aceitou a pasta da Justiça para promover a campanha parlamentar da eleição direta; como Ruy Barbosa aderiu à República nas vésperas do 15 de novembro, para obter, com ela, a almejada federalização das Províncias.

A demonstração dessa atitude de Lafayette vamos colhê-la em seu discurso de 31 de janeiro de 1879: "Os aparelhos constitucionais de que os povos se servem são, diante da alta teoria, inteiramente indiferentes, desde que êles são combinados de modo a produzir o govêrno da Nação pela Nação. É à luz dêstes princípios que a política e a história julgam dos homens, e é à luz dêstes princípios que o meu procedimento há de ser julgado".

E mais adiante: "Quando, senhores, o distinto estadista a quem a Coroa confiou a árdua e gloriosa missão de iniciar a nova ordem de coisas, quando êsse distinto estadista, a quem mesmo as paixões do dia não podem negar um grande vigor de caráter, fêz-me a honra de convidar para tomar parte no seu ministério, eu recusei formalmente o convite. Repugnava, antes de tudo, à minha índole, ser Ministro de Estado; eu preferia viver na sombra, entregue aos estudos de minha predileção a ter uma parte ativa na política do meu país; mas, quando êsse distinto estadista me declarou que a situação nascia para a eleição direta, que a eleição direta não só seria o pensamento capital do ministério, 
como era ainda a razão que determinava a existência do ministério, foram-se-me as hesitações e eu aceitei um lugar no ministério, na convicção de que não me negava a mim mesmo, mas ia pôr-me ao serviço de uma idéia, cuja realìzação importaria restituir à Nação o govêrno de si mesma".

Como era natural, teve Lafayette de suportar duros embates no Parlamento. Diogo Velho o acusava de trazer o barrete frígio no bôlso da casaca de ministro. Dias antes, aliás, respondendo a objurgatória do mesmo senador, limitou-se Lafayette a apelar para o latim no verso de Aulo Pérsio: "Pueri, sacer est locus, extra".. E a Martinho Campos dirigiu como única resposta êste cumprimento: "Pelo que me diz respeito, vendo o nobre deputado no comando desta campanha, eu me tranqüilizo, porque há trinta anos sua excelência comanda batalhas políticas e as tem perdido tôdas"

$\mathrm{Na}$ eleição que se procedeu em Minas, em 1879, para provimento de uma vaga no Senado, formada a lista tríplice, de acôrdo com a Constituição, com os nomes de Lima Duarte, Martinho Campos e Lafayette, foi êste escolhido pelo imperador. "Ser senador do Império", escrevia o Visconde de Taunay, (Memórias, p. 427), "constituía o supremo anelo dos homens do antigo regime. E com razão porquanto a vitaliciedade daquela culminante posição oferecia a máxima garantia a todos os azares e vaivéns da existência política, de que era o coroamento e a última recompensa. A navegar por mares revoltos, inçados de surprêsas e perigos, sujeitos ao embate e à repentinidade dos vendavais, quem podia, com efeito, deixar de ambicionar, cheio de esperançosa impaciência, o pôrto livre de tempestades, calmo e sereno, abrigado de todos os contratempos pela natureza e pelos cuidados da previdência humana?".

Para Lafayette, contudo, não seria o Senado a culminância política. Com a queda de Paranaguá, aos 24 de maio de 1883, foi chamado para constituir o $31^{\circ}$ Gabinete da Monarquia. E, dando preeminência sôbre tôdas à questão 
financeira, em seu govêrno, reservou para si a pasta da Fazenda ${ }^{2}$.

A Proposta de Orçamento e o Relatório por êle apresentados à Assembléia Geral Legislativa, aos 6 de maio de 1884 , são a prova inequivoca de seu conhecimento profundo da matéria e o seu alto descortino a respeito dos negócios do Estado.

Escrevell Lafayette: “Temos, é certo, nas finanças do Império dificuldades, podemos mesmo dizer, dificuldades graves. Mas o estudo refletido, calmo e imparcial, dos documentos oficiais, revestidos de perfeita imparcialidade, firmará a convicção de que essas dificuldades exprimem apenas desordem e perturbação acidentais, e que, para superá-las, nos sobram recursos", (Ministério da Fazenda - Proposta e Relatório apresentados à Assembléia Geral Legislativa pelo Ministro e Secretário de Estado dos $\mathrm{Ne}$ gócios da Fazenda, Lafayette Rodrigues Pereira, Rio de Janeiro, Imprensa Nacional, 1884, p. 4).

E, como se escrevesse para os dias de hoje, acentua Lafayette: "A tendência, motivada pela extrema confiança, de alargar o círculo dos melhoramentos materiais, por certo muito aquém das exigências da nossa civilização, mas sem dúvida além do que comportavam as nossas circunstâncias financeiras, e a facilidade em aumentar serviços, que nâo tinham o cunho de indispensáveis e inadiáveis, criaram-nos o regime dos deficits, e conservaram-nos a êle presos. É êste o ponto capital das nossas finanças, e, como tal, importa que seja estudado com máximo zêlo, e com sentimento da

2. Novamente a falta de coerência política de Lafayette Rodrigues Pereira foi objeto de exploração, por parte dos adversários. "Não há parvajola por aí que se não divirta com o republicanismo do Sr. Lafayette", dizia Ruy Barbosa. E, com o pseudônimo de Salisbury, publicou no Jornal do Comércio, em defesa do presidente do Conselho, uma série de artigos intitulados Féria Política. Êsses artigos causaram sensação e foram posteriormente reunidos em volume sob o título: Traços para a história da oposição em 1883 - Féria Política - Artigos de Salisbury." Rio, Tipografia Nacional, 1884. (Conf. Luiz Viana Filho, A Vida de Ruy Barbosa, edição do Centenário, p. 138). 
mais perfeita imparcialidade. Antes de tudo, para que a questão dos deficits seja bem compreendida na sua natureza e efeitos, cumpre assinalar que, a exemplo da França e de outros povos, temos, paralelo ao orçamento ordinário da despesa, um orçamento extraordinário, igualmente de despesa, isto é, os créditos da tabela $C "$, (p. 11). E mais adiante: "Se a renda continuar a cobrir a despesa ordinária, como aconteceu nos últimos exercícios do decênio, e como, por sólidas razões, é de esperar, teremos que o deficit em cada futuro exercício será determinado tão sòmente pelas despesas dos créditos da tabela $C$, isto é, pelas despesas do orçamento extraordinário", (p. 22).

Digno de ponderação é o capítulo consagrado ao Meio Circulante, em que relembra não representar o papel moeda, pròpriamente dito, "o equivalente do valor, nele inscrito, nem tão pouco representa êsse valor, porque é inconvertível: o seu valor só tem por fundamento "a disposição da lei, que lhe confere a fôrça liberatória, e o consentimento dos que o aceitam como instrumento de aquisição", (p. 59).

$\mathrm{E}$ para os que se olvidam dêstes princípios: "De ordinário os governos, por motivos que são óbvios, emitem papel moeda em quantidade, muito superior às necessidades da circulação, abuso que, como fàcilmente se compreende, procede de não ter o papel moeda em si o valor, que a lei lhe atribui. É sobretudo neste abuso que está o maior perigo do papel moeda.

"Como todo instrumento, que é destinado a satisfazer necessidades sociais, o papel moeda está sujeito à lei da depreciação. $O$ seu valor decresce na proporção em que êle excede à quantidade dos meios de permuta, de que há mister a circulação. E desde que êle se deprecia, aí surgem todos os males e perturbações, inerentes à depreciação da moeda".

Voltemos, contudo, ao orador parlamentar. Lafayette teve muitas oportunidades de pôr em destaque de novo a fôrça de sua erudição, a sua ironia, a sua mordacidade, na filigrana de uma palavra sempre oportuna. Dizia êle: 
"Confesso que nas minhas palavras podia haver alguma malignidade; mas foram ditas de modo cortês"...

Vendo-o na tribuna, assim a êle se refere Afonso Celso Junior: "Estrábico, de óculos, cabeça poderosa, feições acentuadas, Lafayette força as atenções de quem o encara, dando idéia imediata de uma personalidade fora do vulgar". E um conservador, Gomes de Castro, declarava que não poderia deixar de se inclinar diante do presidente do Conselho, porque poucos poderiam reunir como êle talento tão esplêndido e erudição tão vasta.

De seus contactos políticos fora do Parlamento há sem dúvida muito que falar. Um episódio apenas, que me foi referido por Max Fleiuss, meu saudosíssimo amigo, basta para positivá-lo.

Certa vez foi Lafayette procurado por um deputado do Norte, que lhe enviou seu cartão de visita pelo contínuo a fjm de se anunciar. $\mathrm{O}$ presidente do Conselho recebeu-o. E quando o parlamentar se retirava, Lafayette devolveu-lhe o cartão. Ante a recusa de seu interlocutor, que alegava possuir mais cartões, podendo, pois, Lafayette guardar o que the era of erecido, êste redarguiu: "Insisto para que aceite de volta o seu cartão; pode ser-lhe de grande utilidade" . Encabulado, o visitante recebeu-o. Mas, quando foi examiná-lo, fora do gabinete do presidente, corou de vergonha: no verso do cartão havia umas anotações comprometedoras...

De uma feita, na Câmara, um deputado do Ceará indagou quando e como pretendia o govêrno levar a efeito suas anunciadas reformas sôbre o elemento servil. Com a maior seriedade e candura Lafayette assim lhe respondeu: "Nesta sessão e dentro de poucos dias, por meio de um projeto que será submetido à Câmara". E acrescentou: "Não há outro meio de realizar reformas, que dependam de lei, senão por um projeto submetido ao Poder Legislativo"...

Incidente curioso foi o relativo à demissão do ministro da Guerra, Conselheiro Rodrigues Junior. Lafayette dirigiu- 
Ihe uma carta, considerando que "seria um ato acertado a sua retirada do ministério". A missiva estava redigida em têrmos duros, mas polidos.

$\mathrm{O}$ assunto repercutiu no Parlamento. Rodrigues Junior pediu ao presidente do Conselho que declinasse um fato, um êrro que houvesse cometido; ao que retorquiu Lafayette: "A incapacidade não se prova com fatos".

Ante a insistência do antigo ministro, desferiu-lhe o adversário êste golpe mortal: "Não quero, nem devo responder ao discurso do honrado deputado, ex-ministro da Guerra. Já manifestei o meu pensamento a seu respeito. Entendi, era juízo meu, que s. exa. não tinha a aptidão necessária para gerir os negócios da guerra. É juízo meu e devo governar-me pela minha cabeça. Diante dêste juízo, convidei o nobre deputado a retirar-se do ministério. $O$ nobre deputado é homem de espírito cheio de vacilações e de hesitações. Muitas vêzes, diante de suas hesitações, convenci-me de que era realidade e não coisa imaginária a hipótese de Buridan"...

Ao realizar-se, a 3 de junho de 1884 , a eleição do presidente da Câmara, o candidato da oposição foi o mesmo deputado Rodrigues Junior. Foi eleito o candidato governista, Moreira de Barros, pela diferença de dois votos. E, na corrente oposicionista, estiveram contra o govêrno, além do próprio candidato, nada menos que nove deputados liberais. Seguiu-se a isso moção de combate ao Gabinete, apresentada por Cesar Zama, e em cuja votação o presidente do Conselho venceu por escassa maioria. Não era possível a menor ilusão a respeito: chegara a hora da retirada. Lafayette apresenta dignamente seu pedido de demissão ao Imperador, sendo substituido na Chefia do Govêrno, aos 6 de junho de 1884, pelo Conselheiro Manuel Pinto de Souza Dantas.

Quis Sua Majestade, todavia, logo no ano seguinte, aproveitar a capacidade de Lafayette em missão diplomática de alto relêvo. $\mathrm{Na}$ instituição de tribunais arbitrais entre o Chile, de um lado e a França, Inglaterra, Bélgica e 
Alemanha, de outro, para dirimir as questões entre os nacionais dêstes últimos países e o primeiro, em relação a danos causados pelas fôrças militares chilenas, durante a guerra do Pacífico, escolheu-se a D. Pedro II como presidente. Nomeou o monarca ao diplomata e jurista Lopes Neto para o exercício dessas funções. Com a renúncia dêste, cometeu o encargo a Lafayette o qual, havendo desgostado aos países europeus, envolvidos no caso, com os seus pronunciamentos, também não quis continuar, sendo substituído pelo Barão Aguiar de Andrade, que encontrou a fórmula diplomática para solução do litígio.

A 7 de junho de 1889 ascende ao poder o Ministério Ouro Preto, o derradeiro da Monarquia. Fôra o Brasil convidado pelo Govêrno dos Estados Unidos a se fazer representar na Primeira Conferência Interamericana, convocada pelo Secretário de Estado James G. Blaine e que deveria reunir-se em Washington no mês de outubro.

Tencionava Ouro Preto nomear Joaquim Nabuco para chefiar a Missão; mas, por inspiração de Salvador de Mendonça, delibera escolher Lafayette, (conf. Carlos Sussekind DE Mendonça, Salvador de Mendonça, democrata do Império $e$ da República, p. 135). Relutou êle em aceitar a incumbência; mas, terminou acedendo ao convite formulado.

Em meados de julho, Lafayette e Salvador de Mendonça dirigiram-se ao Palácio Itamaratí, no Alto da Tijuca, a fim de apresentar suas despedidas ao imperador. $\mathrm{E}$ eis como Salvador descreve essa visita: "Recebeu-nos na sala de bilhar. Fêz-nos sentar, conversou acêrca das instruções que levávamos e fechou o assunto da nossa missão especial com as seguintes palavras, que dou como as protocolizei: "Estudem com todo o cuidado a organização do Supremo Tribunal de Justiça de Washington. Creio que nas funções da Côrte Suprema está o segredo do bom funcionamento da Constituição norte-americana. Quando voltarem, havemos de ter uma conferência a êste respeito. Entre nós as coisas não vão bem, e parece-me que se pudéssemos criar aqui um tribunal igual ao norte-americano e transferir para êle 
as atribuições do Poder Moderador da nossa Constituição, ficaria esta melhor. Dêem tôda a atenção a êste ponto". (Conf. Salvador de Mendonça, A situação internacional do Brasil, p. 102/3).

Que visão de estadista revelava nesse passo o grande Imperador! A preeminência do Poder Judiciário e a Federação das Províncias, (aliás, já estabelecida pelo decreto n. ${ }^{\circ} 1$, de 15 de novembro de 1889), constituem as colunas mestras da Constituição de 24 de fevereiro de 1891. Tivesse o Visconde de Ouro Preto incluído em seu programa a Federação, como preconizava Ruy e se houvesse realizado a reforma da Constituição Imperial, no sentido da sugestão de Sua Majestade e é provável que não tivéssemos tão cedo a República em nosso país.

Entre a instalação da Conferência Interamericana, a 2 de outubro e a queda da Monarquia, quarenta e três dias decorreram. Os trabalhos em Washington não haviam avançado muito. Cientes os membros da Missão, logo a 15 de novembro, por intermédio do Departamento de Estado, da proclamação da República, viram a 19 os seus poderes confirmados, em telegrama do Ministro das Relações Exteriores, Quintino Bocayuva. Salvador de Mendonça e Amaral Valente aceitaram a ratificação; Lafayette Rodrigues Pereira recusou-a, imediatamente.

Dir-se-á que sua renúncia à Chefia da Missão derivava de sua posição na política brasileira: senador do Império, antigo Ministro da Justiça e antigo presidente do Conselho, a sua inconformidade com a nova ordem estabelecida era compreensivel. Mas, talvez houvesse ainda uma segunda causa, para orientar sua atitude: a sua incompatibilidade com o Ministro das Relações Exteriores.

Quintino Bocayuva fôra o autor principal do Manifesto Republicano de 1870, que Saldanha Marinho assinara em primeiro lugar e do qual Lafayette era o sexto signatário. Sua entrada posterior para os Conselhos da Coroa deve ter-lhe criado prevenções, entre os republicanos. E a 
anotação por êle feita em um caderno particular sôbre Quintino e da qual Antônio Gontijo de Carvalho nos fornece uma amostra, em seu livro Um Ministério visto por dentro, p. 253, lança um jacto de luz sôbre muitas coisas obscuras...

Retornando ao Brasil, recolhe-se Lafayette ao convívio de sua família e de seus livros, esquecido da política e encerrado num invencível silêncio. Vão procurá-lo na chácara da Gávea, à rua Marquês de São Vicente, os mais eminentes juristas, que o reverenciam como mestre. Contava Estevam de Almeida que numa dessas visitas, em companhia de João Mendes Junior, a palestra dêste com Lafayette fôra nos dominios do direito e da filosofia. "Dentro em pouco, êles libravam tão alto, que eu tive de ficar à distância"... Por ocasião da Segunda Conferência da Paz, ia vê-lo tôdas as tardes o Barão do Rio Branco, para mostrar-lhe os despachos de Ruy Barbosa e colher as suas impressões, para orientação da chancelaria...

Redige em 1911, por incumbência do Govêrno, o Projeto de Código de Direito Internacional Privado, a ser submetido, com o Projeto de Código de Direito Internacional Público, de Epitácio Pessoa, à Comissão de Jurisconsultos encarregada da codificação do Direito Internacional. E a República, que não pode prescindir da colaboração de jurista tão eminente, designa-o como membro brasileiro do Tribunal Arbitral de Haia.

Como reminiscência de suas atividades pretéritas, guarda a Grã-Cruz da Ordem de Cristo e as insígnias do oficialato da Ordem da Rosa. Também conserva o título de Conselheiro, que mantinham e de que se orgulhavam dois presidentes da República.

De sua Missão nos Estados Unidos trouxera como lembrança uma cadeira que pertencera a George Washington, dádiva do Govêrno Americano. E colhera, em sua visita a Mount Vernon, um pouco de terra, alguns seixos e umas fôlhas de hera, junto ao túmulo do herói, e que, como relíquia, dividiu um dia com Cesário Alvim. 
Também visitei duas vêzes, emocionado, em 1947 e enı 1954, a mansão de Washington. A casa, de puro estilo colonial, guarda a serenidade da morte. Contemplei, através das portas envidraçadas, os livros de sua biblioteca. Vi os objetos de uso do herói. O leito em que faleceu. Em meio da escada estreita, que conduz ao pavimento superior, o velho relógio de carvalho, que me trouxe à memória os versos de Longfellow:

By day its voice is low and light;

But in the silent dead of night. .

Fui depois ao terraço do fundo: as águas do Potomac continuavam a deslizar suavemente e nada podiam revelar sôbre os encontros que presenciaram entre George Washington e o general Lafayette. . "L'éternité est une pendule, dont le balancier dit et redit sans cesse ces deux mots seulement, dans le silence des tombeaux: "Toujours! jamais! Jamais! toujours!" (JAcQues BridaINe).

Um acidente em sua casa, cinco anos antes de sua morte, causara a Lafayette Rodrigues Pereira uma fratura não consolidada do fêmur e a sua permanente imobilidade. Em sua idade provecta, a artério-esclerose generalizada foi fazendo a sua marcha fatal.

Os anos passaram. O troar dos foguetes, as sirenas das fábricas e o repique dos sinos chegaram até o recolhimento da Gávea anunciando o despertar do Ano Novo. Primeiro de janeiro de 1917! Entrava em vigor o Código Civil.

Muito poucos da velha geração nele colaboraram, o Código representava sobretudo uma obra da gente moça, da geração que sucedera à dos consagrados jurisconsultos do Império. Iam-se de vez as antigas Ordenações, Leis, Decretos, Alvarás e Resoluções dos reis de Portugal que continuavam ainda, na parte não revogada, a constituir as normas de nosso Direito Civil. 
Lafayette pôs-se a reconhecer que o seu tempo já se fôra. Vivia no momento inteiramente esquecido dos homens, como um "deus proscrito".

A 29 de janeiro de 1917, às dez horas da manhã, teve na morte a sua libertação. Não a aguardou de pé, a espada nua, como Cyrano. Ela tinha de vir, porém, cautelosamente, para que Lafayette não a percebesse; pois, de outra maneira, haveria de compor, para aguardá-la, um sorriso de ironia... 